\title{
Electricity Access Options Appraisal in Malawi: Dedza District Case Study
}

\author{
Aran Eales \\ Damien Frame \\ Peter Dauenhauer \\ Energy for Development Research Group \\ University of Strathclyde \\ Glasgow, UK \\ aran.eales@strath.ac.uk
}

\author{
Blessings Kambombo \\ Philimon Kamanga \\ ENGAGED Programme \\ Concern Universal Malawi \\ Dedza, Malawi \\ Blessings.kambombo@concern-universal.org
}

\begin{abstract}
An energy audit has been conducted for the Dedza district in Malawi, which required the development and implementation of a multidisciplinary options appraisal methodology involving a literature review; solar, wind and hydro resource assessment; household and business surveys; focus group discussions and expert interviews. A decision making tool was developed to score and rank renewable energy technologies based on defined input criteria. Due to low income levels and limited capacity, small scale, low access, technologies such as pico-solar products were found to have the highest potential for widespread uptake over the district. Other innovative uses of solar energy including solar home systems and productive uses of solar also score highly due to good solar resource in the district, modularity and ease of implementation. Wind and hydro systems are ranked lower due to limited resource and lack of local capacity to implement.
\end{abstract}

Index Terms-- geographic information systems, renewable energy sources, rural areas, social factors, technology planning

\section{INTRODUCTION}

Developing countries face extensive challenges in delivering electrical energy access, with average Sub-Saharan African electrification currently at $68 \%$ in urban areas and $14 \%$ in rural areas [1]. Alternative solutions to traditional electricity grid supply are essential to overcome the continuing challenges in the delivery of reliable and affordable electricity. The UNDP states that energy access is an enabling factor for human development [2], however according to the World Bank Sustainable Energy for All database (2016), access to the national electricity grid in Malawi is currently just $9.8 \%$ with only $7.2 \%$ of the population having access to modern cooking fuel [3]. As a result, the lighting and cooking needs of the vast majority of the population are served by traditional, carbon-based sources of energy, such as charcoal and wood for cooking; and kerosene, candles and non-rechargeable batteries for lighting. Existing energy policy in Malawi is outdated and ineffective, with rural electrification having focussed primarily on expensive grid extension, with little progress or impact. However, the energy sector in Malawi is currently mobilising to address these challenges, with evidenced increase in bi-lateral donor support for clean cooking and renewable energy programmes in recent years. In addition to this, the Government of Malawi has issued a new National Energy Policy and Renewable Energy Strategy; both due to be launched in 2017 in parallel with Malawi's Sustainable Energy for All Action Agenda. All include significant targets for off-grid renewable energy technologies. Within this context, development and use of planning and decision making frameworks that can assess the social, economic and technical viability of different rural electrification strategies are essential to ensure the socioeconomic return on energy access investments in Malawi is maximised. In this paper, an options appraisal methodology for Renewable Energy Technology (RET) is developed that incorporates market assessment, resource assessment and technology ranking techniques. Section II describes the market assessment methodology and results. Section III describes the renewable energy resource assessment. A framework for assessing RET options is set out in Section IV along with a discussion of RET options for the Dedza case study. Conclusions and future work are provided in Section V.

\section{DEDZA MARKET ASSESSMENT}

\section{A. Methodology}

A literature review was conducted to ascertain relevant background information from academic studies and government and district policy documents. Structured questionnaires were designed and used to determine current and expected energy use, ability and willingness to pay, and relevant socio-economic information from households and businesses. These surveys were conducted by specially trained field enumerators using KoBoToolbox [4], an open source suite of tools enabling collection, analysis and storage of field data by utilising smart phones and uploading to a digital server. Data was collected from 4 Traditional Authorities in Dedza: Tambala, Kaphuka, Kachindamoto and Kasumbu, with a total of 336 surveys conducted. A stratified
Sponsors for the research: Irish Aid funded Concern Universal to undertake the Enhancing Governance, Advocacy, Growth, and Energy in Dedza (ENGAGED) Programme, of which the energy audit carried out by University of Strathclyde was part of. 
random sample was pursued for the surveys, with purposive sampling based on pre-defined socio-economic strata and geographic considerations as suggested by partner NGO Concern Universal Malawi.

Focus group discussions (FDGs) were conducted, where people from similar backgrounds or experiences within village clusters were brought together to discuss a specific topic of interest related to the energy audit research. Expert interviews were conducted to analyse opinions on renewable energy in Malawi relating to different themes (energy projects, policy, capacity, Dedza specific, solar market mapping, and expertise specific). Interviewees included renewable energy practitioners, government officials, executive officers, and NGO staff. The semi-structured interview techniques were recorded and transcribed, and thematic coding was conducted to draw out cross cutting themes.

\section{B. Dedza Overview}

Dedza is the third largest district in the Central Region of Malawi, located $86 \mathrm{~km}$ South of Lilongwe and covering a total land area of $3,624 \mathrm{~km}^{2}$; approximately $4 \%$ of the total land surface area $\left(94,276 \mathrm{~km}^{2}\right)$ of Malawi [5]. The district is divided into three topographic zones: the Lilongwe Plain, Dedza Highlands, and the Escarpments. The majority of the population live in the central region of Dedza district, North West of Dedza town and South East of Lilongwe, apart from Changoni and Dedza forest which have low populations. The annual population growth rate in the district for the years 1998-2008 was $2.6 \%$. The district has increased to 105,110 households while the land holding size for Dedza has drastically reduced from 10.56 ha in $1995 / 1996$ to 0.7 ha in 2009/2010 [6].

Poverty levels range between $70 \%-99 \%$ of the population living under $\$ 2 /$ day [7]. There is a strong correlation between population density and poverty levels. The high population zones in the centre of the district correspond to lower poverty levels, with the lowest poverty levels being found in Dedza Town and the highest in the north towards Salima and the South West towards Mozambique. Residents of Dedza have a low life expectancy of 45.4 years and the fertility rate is extremely high at 5.8 [6].

\section{Business and Household Profile and Income}

Most businesses in Dedza are small with a monthly average income of less than 500,000 MKW (690 USD), with only $15 \%$ having an average monthly income of more than this. The business types include: grocery sales, bakery, barber shop, video show, phone charging, tailoring, clothes sales, grain mill, welding, carpentry, internet access, hardware shop, printing and photocopying, fishmonger, mobile money agent, bicycle repair, agro dealer, produce trading, butchery, bar and making stoves. $25 \%$ of businesses interviewed had access to a bank account, $30 \%$ had access to a mobile account and $78 \%$ had access to credit.

The majority of household survey respondents were female (64\%) and aged 18 - 35 (51\%). Respondent occupations in this sample are mainly peasant farmers and housewives, with only a few semi-commercial farmers, business people, and wage labourers. The average household size was 5.63 persons, with the highest number found in the age category of $7-17$ years. This reflects the national statistic of Malawi with high fertility rates and a bottom heavy population pyramid. $93 \%$ of respondents have crop production as their main source of income, with animal farming, casual labour, beer brewing, and grocery, charcoal and firewood sales as other options given. The majority of household incomes are below 20,000 MKW (28 USD) per month, with a mean of $14,413 \mathrm{MKW}$ (20 USD), and maximum of 150,000 MKW (207 USD). Food remains the highest expense of the average income, followed by cloth and then energy.

\section{Energy Use in Dedza}

\section{1) National Grid}

Fig. 2 shows the existing national grid network, with data taken from the National Roads Authority [8] and discussions with Department of Energy Affairs. The Malawi Rural Electrification Programme is currently implementing phase eight of their electrification program which will see four new trading centres electrified in Dedza, with the potential to connect other customers or trading centres in close proximity, if they can afford the connection cost. There are currently no minigrids operational in Dedza. Only $6.4 \%$ of the district is currently served by the grid [9], and no plans currently exist to expand the grid towards the remote rural plains to the West and the mountains to the North. In addition, even areas in the grid catchment area have high populations that cannot connect due to lack of purchasing power to make the initial connection.

Figure 2: Existing Grid Connection in Dedza [8]

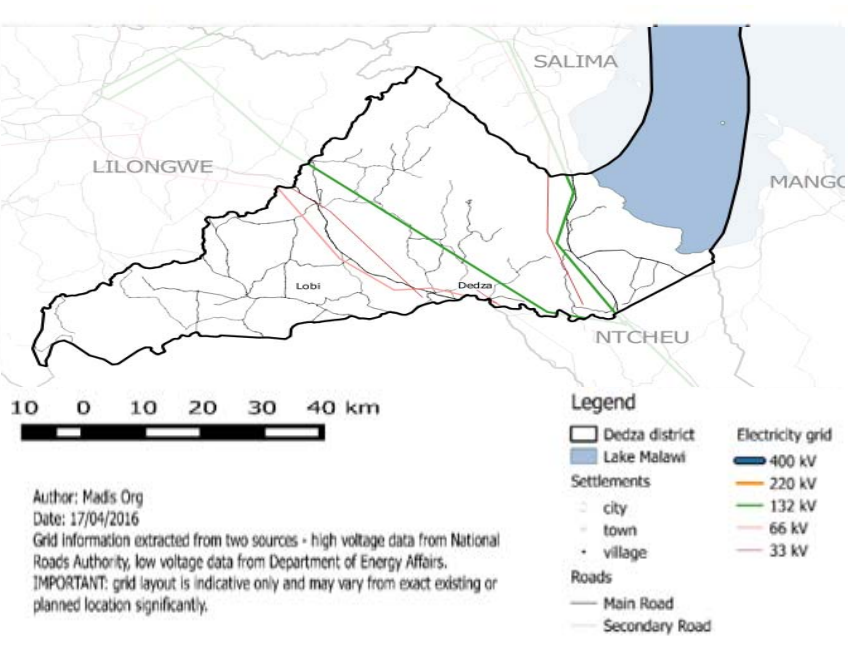

2) Business and Household Energy

Dry cell batteries in a lamp are the most popular form of primary lighting in households, with most houses having no secondary lighting present. Candles are also used for both primary and secondary lighting. Batteries also represent the highest use of energy for rural businesses. Household appliance ownership is generally low, with radios being the most common appliance. In grid connected trading centres, maize milling incurred the highest electricity cost, indicating that it is a service in demand of the surrounding communities. $92 \%$ of businesses use electricity (grid and non-grid) for 
lighting, which represents the primary use of electricity. However, other business electrical uses for electricity include refrigerators, TV screens, and hair driers in saloons, with the most common being phone charging and shaving machines. In terms of ownership of electrical generators, pico solar product (PSP) ownership was highest, followed by $12 \mathrm{~V}$ batteries and solar home systems (SHS), with no diesel generator ownership, as outlined in Table 1.

TABLE I. ENERGY STATISTICS FOR HOUSEHOLDS AND BUSINESSES

\begin{tabular}{|l|c|c|}
\hline Energy Parameter & Household & Businesses \\
\hline $\begin{array}{l}\text { Primary Energy Use } \\
\text { (ordered) }\end{array}$ & $\begin{array}{c}\text { Firewood, Dry cell } \\
\text { batteries, candles, } \\
\text { charcoal, paraffin }\end{array}$ & $\begin{array}{c}\text { Dry cell batteries, } \\
\text { Firewood, candles, } \\
\text { charcoal, paraffin }\end{array}$ \\
\hline PSP ownership & $5 \%$ & $18 \%$ \\
\hline SHS ownership & $2.5 \%$ & $13 \%$ \\
\hline 12V Battery ownership & $3.5 \%$ & $16 \%$ \\
\hline $\begin{array}{l}\text { Main appliances } \\
\text { (ordered) }\end{array}$ & Radios, stereo, TV & $\begin{array}{c}\text { Radio, TV, Stereo, } \\
\text { computer, fridge }\end{array}$ \\
\hline
\end{tabular}

Fig. 3 shows the household monthly energy spend. The mean monthly spend is highest for paraffin, followed by candles and then batteries. However, the maximum spend stated is highest for batteries, followed by candles then paraffin. For the respondents interviewed, the indicative amount spent on lighting is approximately 1,000 MWK (\$1.34) per month.

Figure 3: Household Monthly Energy Spend (MWK)

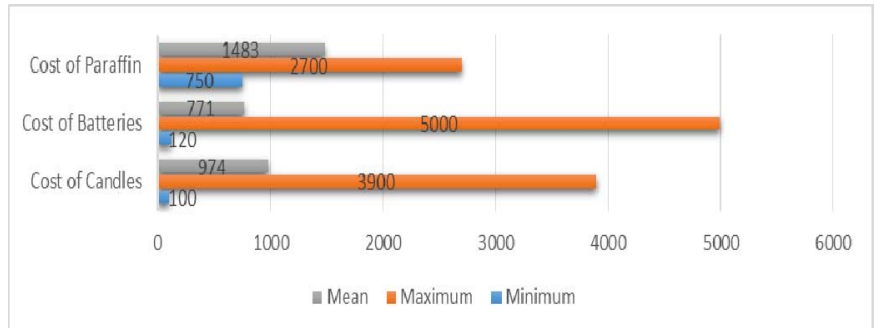

\section{E. Solar Energy use in Dedza}

Solar PV Equipment is currently being used in the district but is not widespread. 13\% of the businesses interviewed currently sell solar products, while $31 \%$ indicated that they would be interested in selling renewable energy (RE) equipment, and $28 \%$ reporting that they had received enquiries from customers regarding the purchase of RE equipment. A variety of solar PV products are available in Dedza town from shop keepers; mostly cheap products with no certification or no warranty. Solar energy is perceived by locals to help improve the performance of their children at school as they will be able to study at night, and also bring economic benefits by eliminating ongoing fuel costs (although upfront costs can still be prohibitive for some). However, in the main, most solar products were still considered as unaffordable by most communities.

Different business models for deploying PSP have been used elsewhere in Malawi and could be replicated in Dedza. These include direct sales, rental or Rent to Own and Pay as You Go, which have been implemented by both private sector and NGOs. Direct sale methods have challenges of access to capital and finding competent entrepreneurs willing to take a risk on upfront purchasing. PSP projects were deemed more likely to be successful if initial training of entrepreneurs and sensitisation of prospective consumers is conducted in the villages.

\section{RENEWABLE ENERGy ReSOURCE ASSESSMENT}

A district wide renewable energy resource assessment was made for solar, wind and hydro and mapped using Geographical Information System (GIS) layering software.

\section{A. Solar Resource Assessment}

Fig. 4 shows the solar resource for Dedza. It can be seen that the Global Horizontal Irradiation (GHI) ranges from 4.5 $\mathrm{kWh} / \mathrm{m}^{2}$, in the mountainous areas to the West and East of Dedza town, to up to the $6 \mathrm{kWh} / \mathrm{m}^{2} /$ day found in TA Kachindamoto close to Lake Malawi. Compared to the rest of Malawi, Dedza has a slightly lower solar resource during the winter months; however the annual solar resource available is still high and suitable for solar PV installations across the district.

Figure 4: Solar Resource of Dedza [10]

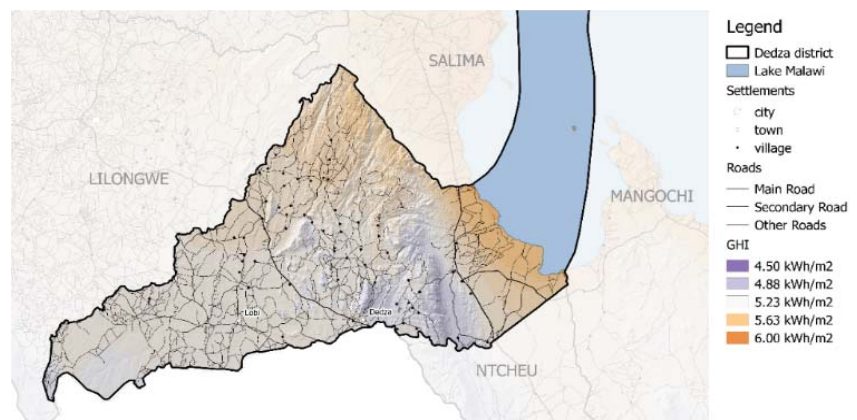

The seasonal variation follows a peak during March, following a period of low solar resource during June and July, and a second, greater peak occurring in October. Solar PV systems will need to be designed with the lowest monthly solar resource in mind $\left(4.51 \mathrm{kWh} / \mathrm{m}^{2} /\right.$ day in July) and load profiles should be explored seasonally.

\section{B. Wind Resource Assessment}

A wind map at $18 \mathrm{~m}$ (Fig.5) has been modelled using a wind resource dataset that utilises a variety of sources including measured data and satellite imagery processing [11]. The resource is generally low in the East and West of the district $(2-3 \mathrm{~m} / \mathrm{s})$, but is slightly higher in the centre of the district to the West of the Dedza escarpment (4-5 m/s). Due to the high variability and small pockets of worthwhile resource, wind power is less viable as a technology in Dedza.

\section{Figure 5: Wind Resource of Dedza [11]}

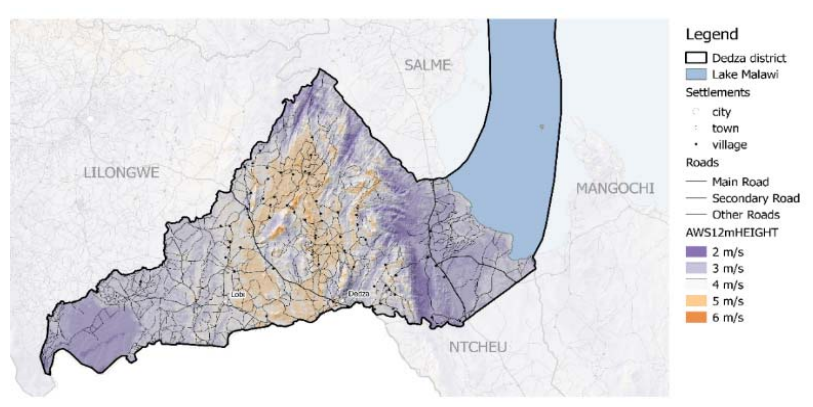


It can be seen in Fig. 6 that the seasonal profiles for solar and wind generally follow the same pattern and offer little complementarity.

Figure 6: Wind and Solar Resource Complementarity (solar=blue, wind $=$ red)

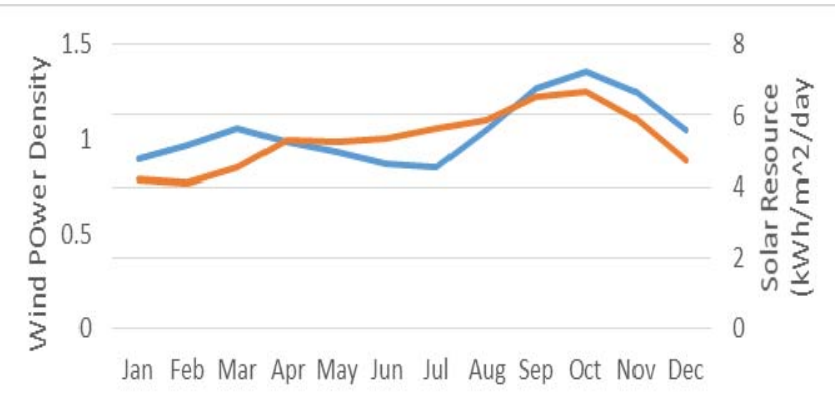

\section{Hydro Resource Assessment}

GIS mapping of all perennial rivers in Dedza was performed. For each river a slope analysis was conducted to determine the slope percentage for each section of river, and a visual inspection of the proximity of energy using settlements to the perennial rivers conducted. Areas with high slope in the vicinity to settlements were selected, and for each river selected a profile analysis was completed, charting the slope over the distance, from which the head can be estimated.

Dedza receives an average of $1109.8 \mathrm{~mm}$ of rainfall per year, or $92.5 \mathrm{~mm}$ per month, with the driest weather in August and the wettest in January [12]. There has also been extreme rainfall variability over the past three decades, with periods of excessively high rainfall as well as extremely little rainfall [13]. Both excess and limited rainfall can affect hydro systems negatively, as they depend on reliable rainfall throughout the year.

Indicative results show that there exists a head resource in Dedza (the largest being $900 \mathrm{~m}$ over $30 \mathrm{~km}$ ), but that there are very few settlements close to the rivers at present. It is likely that flow resources exist to power small micro-hydro schemes, but more research is required to quantify the exact flow and associated energy available. Identified risks relates to flow resources being erratic due to climate change and a future reduction in flow resources due to deforestation causing siltation of the rivers.

\section{Renewable Energy Technology Options} APPRAISAL

\section{A. RET Selection Methodology}

Each technology is presented with a technical overview including relevant information about implementation or case studies that have taken place in Malawi. A rating system was devised, whereby each technology for consideration could be assessed on a variety of criteria related to their suitability for implementation in Dedza, including scalability, appropriateness to local resource, affordability, level of access offered, and local capacity to implement. The different criteria and the associated rubric for scoring is outlined in Table 2. The scores (out of 3 ) for each parameter were given by a panel of experts, taking into account all influencing parameters for successful implementation of the technology gathered from previous analysis in this study.

TABLE II. SCORING RUBRIC FOR TECHNOLOGY CHOICES

\begin{tabular}{|c|c|c|c|}
\hline \multirow{2}{*}{ Indicator } & \multicolumn{3}{|c|}{ Score } \\
\hline & 1 & 2 & 3 \\
\hline $\begin{array}{l}\text { A: } \\
\text { Scalability } \\
\text { * Rating is } \\
\text { given in } \\
\text { respect to the } \\
\text { next } 5 \text { years, } \\
\text { and within } \\
\text { Dedza } \\
\text { district }\end{array}$ & $\begin{array}{l}\text { Very little scope } \\
\text { to scale } \\
\text { technology. } \\
\text { Beneficiaries } \\
\text { limited to certain } \\
\text { socio-economic } \\
\text { groups. Potential } \\
\text { to reach }<10 \% \text { of } \\
\text { the population }\end{array}$ & $\begin{array}{l}\text { Some potential to } \\
\text { scale, limiting } \\
\text { factors make it } \\
\text { challenging to } \\
\text { reach large } \\
\text { majorities. } 10- \\
50 \% \text { of the } \\
\text { population can be } \\
\text { reached. }\end{array}$ & $\begin{array}{l}\text { Potential to } \\
\text { reach a large } \\
\text { proportion (over } \\
50 \% \text { ) of the } \\
\text { population in } \\
\text { Dedza. }\end{array}$ \\
\hline $\begin{array}{l}\text { B: } \\
\text { Appropriate } \\
\text { to local } \\
\text { renewable } \\
\text { energy } \\
\text { resource }\end{array}$ & $\begin{array}{l}\text { The availability } \\
\text { of local resource } \\
\text { is very low, and } \\
\text { not appropriate. }\end{array}$ & $\begin{array}{l}\text { There is some } \\
\text { availability of } \\
\text { local resource for } \\
\text { the technology, } \\
\text { but it is not ideal. }\end{array}$ & $\begin{array}{l}\text { Local resource is } \\
\text { appropriate and } \\
\text { ample for the } \\
\text { requirements. }\end{array}$ \\
\hline $\begin{array}{l}\text { C: } \\
\text { Affordability }\end{array}$ & $\begin{array}{l}\text { Expensive, } \\
\text { limiting } \\
\text { beneficiaries and } \\
\text { number of } \\
\text { projects/products } \\
\text { deployed }\end{array}$ & $\begin{array}{l}\text { The product is } \\
\text { reasonably } \\
\text { priced, however } \\
\text { there will be } \\
\text { some who cannot } \\
\text { afford it. }\end{array}$ & $\begin{array}{l}\text { Cheap, with a } \\
\text { low threshold of } \\
\text { purchasing } \\
\text { power required } \\
\text { to buy it. }\end{array}$ \\
\hline $\begin{array}{l}\text { D: Level of } \\
\text { Access } \\
\text { Offered }\end{array}$ & $\begin{array}{l}\text { Low level of } \\
\text { access offered, } \\
\text { only basic } \\
\text { services are } \\
\text { covered. }\end{array}$ & $\begin{array}{l}\text { Some level of } \\
\text { access results in } \\
\text { impact on the } \\
\text { user's life, } \\
\text { beneficial but not } \\
\text { significant }\end{array}$ & $\begin{array}{l}\text { Significant } \\
\text { impact. A } \\
\text { modern reliable } \\
\text { source of } \\
\text { electricity. }\end{array}$ \\
\hline $\begin{array}{l}\text { E: Local } \\
\text { capacity to } \\
\text { Implement }\end{array}$ & $\begin{array}{l}\text { Local } \\
\text { organisations } \\
\text { have little or no } \\
\text { experience in } \\
\text { implementing } \\
\text { the technology }\end{array}$ & $\begin{array}{l}\text { Some experience } \\
\text { has been had but } \\
\text { additional } \\
\text { capacity building } \\
\text { and training is } \\
\text { required }\end{array}$ & $\begin{array}{l}\text { Previous } \\
\text { implementation } \\
\text { exists and little } \\
\text { or no additional } \\
\text { training } \\
\text { required. }\end{array}$ \\
\hline
\end{tabular}

\section{B. Technology Options}

1) Pico Solar Products (PSP)

PSP offer a relatively low financial entry point for consumers, economic and health benefits from replacing kerosene and batteries, and can utilise the good solar resource in Dedza. Manufacturers and distributors cite the concept of the 'energy ladder', whereby in the long-term consumers progress from cheaper products to more expensive and highly functional products. Limitations of PSP include the low level of access offered by the technology, reliance on imports (Malawi suffers serious currency fluctuations), and for some consumers, the low ability to pay even for the cheapest products.

2) Solar Home Systems (SHS)

As discussed, the solar resource in Dedza is suitable for implementing SHS, and the falling cost of PV in recent years makes installed systems a more cost-effective method of supplying amenity power for lighting and appliances. An additional benefit is the increased level of access for users 
compared to PSP systems. Challenges in implementing SHS are the high upfront costs, lack of capacity of local installers and operators compromising installation and maintenance standards, and a dependence on imported equipment which has additional costs. A lack of proven business models for SHS in Malawi (and across Sub-Saharan Africa) represents another major challenge for the successful implementation of SHS.

\section{3) Productive Use of Solar PV}

Malawi has a mainly agriculture-based economy and as a result agro-processing demand is very high. Productive uses of energy (PUE) offer cost recovery of RE capital through household and/or community energy related enterprises. PUE can contribute to the energy system's sustainability and can build on already existing development initiatives among the rural communities. PUE examples include maize milling, barbershops, cold drinks refrigeration, mobile phone charging and video showing, all of which can generate significant income. Solar powered irrigation means that farmers can grow crops outside the rainy season, extending the growing season and increasing income. Solar irrigation has been identified as a key PUE, with a high potential in Malawi due to the heavy reliance on rain fed agriculture. An identified risk was that Dedza receives a lower solar resource from May to August which should be accommodated in the design of the solar irrigation system.

\section{4) Micro-hydro Power}

Hydro power generally has the lowest cost of energy compared to other alternatives and can provide high levels of access reliably, provided a sufficient resource is present. Malawi currently gets almost $100 \%$ of its power from large hydro schemes, and there are a considerable number of micro hydropower plants still functioning, such as Livingstonia micro hydropower in Rumphi, and Bondo Village in Mulanje [14]. A study by the Japan International Cooperation Agency [15] identified priority locations with potential for small hydro power in Malawi, none of which are in the Dedza region. Hydro power requires significant technical expertise to carry out detailed feasibility studies, civil works and electrical connections to user loads, as well as carrying out Environmental Impact Assessments and navigating a complicated regulatory environment. Another challenge is the effect of environmental degradation due to farming activities in upstream rivers, deforestation due to firewood and charcoal production, and climate change. Another major barrier for small hydropower development in Malawi is limited financial capacity, with few private investors or donors interested in the development of off-grid small hydropower stations.

5) Solar PV Mini grids

A mini grid can be defined as linking together demand points within a limited area without connection to the main grid, considered as in-between a main grid and a standalone experience. There is a consensus on the role of mini grids in Malawi to complement the overwhelmed national utility power supply; The Department for International Development (DFID) has suggested that mini grids would be the most appropriate way of gaining access to electricity for over 4.5 million Malawians [16]. To date, Malawi has had some experience with mini grids in various models and approaches using different technologies i.e. hydro, solar and wind $[17,18]$. Mini grids present a significant opportunity to both enhance energy access and promote private sector participation in energy delivery. However, evidence of a sustainable business model for mini grids systems in Malawi has yet to be delivered.

\section{6) Small Wind Turbines (SWT)}

SWT offer low carbon and cost competitive solutions for rural off-grid energy systems and although costs of fossil fuel systems are steadily rising, SWT costs have been shown to be falling in recent years [19]. As demonstrated by Wind Empowerment [20], opportunity exists for local manufacture of SWT which has value chain and job creation benefits over solar PV. Conversely, wind turbines need increased maintenance compared to solar PV due to moving parts and exposure to the elements. Dedza has some areas of reasonable wind resource $(4 \mathrm{~m} / \mathrm{s}$ at $18 \mathrm{~m}$ hub height), however due to the variability of the wind, an individual site assessment for each proposed project would be needed to $\log$ wind speeds, increasing the project costs and timelines. Low complementarity between solar and wind was found, further reducing an argument for including wind turbines in a hybrid system, as energy production will only marginally increase when both technologies are implemented in hybrid. These reasons, including the fact that wind technology requires significant technical expertise which is not freely available in Malawi, makes wind power a relatively risky technology.

\section{Result of RET Selection}

The scores given on each rating parameter according to the rubric presented in Table II are shown in Table III below, ranked with the highest scoring technology first.

TABLE III. RENEWABLE ENERGY TECHNOLOGY SCORES

\begin{tabular}{|l|c|c|c|c|c|c|}
\hline Technology & A & B & C & D & E & TOTAL \\
\hline Pico Solar Products (PSP) & 3 & 3 & 3 & 1 & 3 & 13 \\
\hline Solar Home Systems (SHS) & 2 & 3 & 2 & 2 & 2 & 11 \\
\hline Productive Use of Solar PV & 1 & 3 & 2 & 3 & 2 & 11 \\
\hline Micro Hydro Power & 1 & 2 & 2 & 3 & 1 & 9 \\
\hline Solar PV Minigrids & 1 & 3 & 1 & 3 & 1 & 9 \\
\hline Small Wind Turbines & 1 & 2 & 2 & 2 & 1 & 8 \\
\hline
\end{tabular}

The analysis indicates small-scale solar technology is the most viable technology option. There is a reliable resource, the technology is modular, offers a lower entry point, and the cost reduction in recent years offers further economic gains. Conversely, wind and hydro technologies scored lower as higher resource uncertainty necessitates detailed, more costly feasibility studies with accurate resource monitoring to allow confidence to pursue projects. This, coupled with the lack of capacity to implement these more niche technologies make them unsuitable in the short term. For these technologies to be economically viable and effective enough to be considered as medium to long term electrification strategies, will require considerable capacity building investment. The capacity gaps and ability to pay also affect the viability of solar minigrids. However, given the high level of resource available, this 
technology offers the best potential for medium to long term strategies for expanding off-grid electrification, and achieving higher levels of access that can satisfy high power appliance demand, such as cooking.

\section{CONCLUSIONS AND FUtURE WORK}

Dedza has a population with very low income levels and although a desire for energy is present, there is a low ability and willingness to pay. This factor, coupled with relatively low capacity to implement relatively larger and more complex RETs such as wind and hydro, makes small scale solar applications, especially PSP and SHS most suitable at this time for practitioners and NGOs to pursue. Although higher levels of energy access such as mini-grid electrification may be desirable politically, the reality remains that the business case and overall sustainability prospects are weak in the immediate 5-year time window considered. The analysis of Dedza district indicates electrification efforts should be undertaken hand-in-hand with micro economic development support, linking solar energy solutions to productive uses that drive local economic growth. Whilst focussing on these areas in the short term, it is envisioned that technologies offering greater levels of access should become more affordable and economically viable over time. Long term planning of electrification programmes requires ongoing monitoring and forecasting of the cost of technologies and income levels to update options appraisals and in-turn support the deployment of solar mini-grids in parallel with national grid expansion. There is a growing need for a complementary top-down (grid expansion) and bottom-up (off-grid expansion) approach to rural electrification that converges to provide a more economically viable, technically resilient and efficient energy infrastructure, offering greater security and availability of supply to customers at affordable tariffs.

This work demonstrates the importance of a comprehensive options appraisal approach to forming rural electrification strategy. The value of a detailed market assessment and resource assessment to guide localised strategy and investment has been demonstrated. Although national programmes in Malawi may be advocating sizeable hybrid mini-grids and national grid extension, the analysis presented here clearly indicates that for the Dedza area, strategy to progress electrical energy access should start at the most basic levels and be supportive of, and linked to, wider economic development strategy. The methodology set out in this paper can be used as a guide in future project planning in other districts by local government and other actors in the sector. The three tier scoring method allows rapid comparison of technology over several indicators, however further work will include a more granularised rubric to capture an enhanced perspective on technology choices. Further indicators could be included such as project lifetime, reliability, and potential re-use of the product. Similarly, a weighting system could be applied to the scoring for more detailed analysis, and Multi Criteria Decision Analysis (MCDA) methodologies can be utilised to further investigate technology choices and electrification strategies taking into consideration a range of criteria specified by key stakeholders. It should be noted that the study is a snapshot of district energy use which is constantly changing. The results may be accurate for the next 5 years, by which time the cost of other technologies may reduce, the renewable energy resource assessment data may be more accurate, and the income levels may increase, all of which will change viability and priorities of technology choice.

\section{ACKNOWLEDGMENT}

The authors gratefully acknowledge the input and review efforts of Irish Aid as well as contributions from Madis Org of Wind Empowerment for assitance with the GIS Mapping included in the report.

\section{REFERENCES}

[1] World Bank (2015). World Development Indicators [Online]. Available:http://databank.worldbank.org/data/reports.aspx?source=worl d-development-indicators

[2] United Nations Foundation (2014) Achieving Universal Energy Access. [Online]. Available: http://www.unfoundation.org/what-wedo/issues/energy-and-climate/clean-energy-development.html

[3] World Bank (2016). Sustainable Energy for All database [Online]. Available: http://www.se4all-africa.org/se4all-in-africa/countrydata/malawi/

[4] KoboToolbox (2017).[Online]. Available: http://www.kobotoolbox.org/

[5] Dedza District Council, Government of Malawi (2010). Dedza district state of environment and outlook

[6] Dedza District Council, Government of Malawi (2013). Dedza District Socio Economic Profile 2013-2018

[7] Worldpop (2015). World population and poverty data extract for Malawi. [Online]. Available: http://www.worldpop.org.uk

[8] Malawi National Roads Authority (2006). Map of existing and proposed transmission lines and generation stations.

[9] National Statistics Office (NSO) (2012). Malawi Demographic and Health Survey, 2010. NSO, Zomba, Malawi.

[10] IRENA (2016). Global Atlas for Renewable Energy. [Online]. Available: http://irena.masdar.ac.ae

[11] AWS Truepower, 2016. Wind Map dataset extract for Malawi. [Online]. Available: https://dashboards.awstruepower.com.

[12] Climate Temps (2016) Rainfall, Dedza, Malawi [Online]. Available: http://www.dedza.climatemps.com/map.php

[13] Malawi Government, (2010) "State of the Environment Report," Ministry of Natural Resources, Energy and Environment, Lilongwe

[14] International Centre on Small Hydro Power (ICSHP) (2013). World Small Hydropower Development Report 2013 [Online]. Available: http://www.smallhydroworld.org/fileadmin/user_upload/pdf/Africa_Ea stern/WSHPDR_2013_Malawi.pdf

[15] Japan International Cooperation Agency (JICA) (2003). Master plan study on rural electrification in Malawi

[16] Department for International Development (2013) Low Carbon Mini Grids [Online]. Available:

https://www.gov.uk/government/publications/support-study-on-greenmini-grid-development

[17] Mulanje Electricity Generating Agency (MEGA) (2017) [Online]. Available: http://www.mega.mw/

[18] IODPARC (2012), Evaluation of Off-grid Community Managed Renewable Energy Projects in Malawi [Online]. Available: https://pure.strath.ac.uk/portal/files/54225713/MREAP_Malawi_Off_gr id_evaluation_2012_.pdf

[19] Alliance for Rural Electrification (2012) the potential of small and medium wind energy in developing countries [Online]. Available: http://www.ruralelec.org/fileadmin/DATA/Pictures/07_Publications/A RE_Small_Wind_Position_Paper.pdf

[20] Wind Empowerment (2017) Association for the development of locally manufactured small wind turbines [Online]. Available: www.windempowerment.org 